\title{
Pathogenicity and seasonal occurrence of Henneguya creplini (Protozoa, Myxosporea) on the gills of perch Perca fluviatilis in central Finland
}

\author{
Ahti Haaparanta ${ }^{1}$, E. Tellervo Valtonen ${ }^{1}$, Rudolf W. Hoffmann ${ }^{2}$ \\ ${ }^{1}$ Department of Biology, University of Jyväskylä, SF-40100 Jyväskylä, Finland \\ ${ }^{2}$ Institut rür Zoologie und Hydrobiologie, Tierärztliche Fakultät der Universität München, D-80539 Munich, Germany
}

\begin{abstract}
Between February 1986 and November 1987 a total of 711 perch Perca fluviatilis from 4 lakes of differing water quality in central Finland were examined for Henneguya myxosporeans. Infection varied from 26.5 to $39.6 \%$ in these lakes and no relationships were found between the pollution level of the lake and the prevalence of infection. $H$. creplini was the dominant species, representing over $95 \%$ of the plasmodia with mature spores. H. psorospermica was encountered very rarely. Histological studies on material collected between October 1989 and September 1990 revealed that the majority of plasmodia were located between secondary lamellae in the gill epithelium. Both the prevalence of infection and development of $H$. creplini plasmodia displayed a seasonal pattern in all lakes. Plasmodia with mature spores occurred mainly in spring and early summer, whereas early sporogonic stages were found throughout the year Younger fish were more heavily infected in most cases. The plasmodia of $H$. creplini were found to be in close contact with the host blood system. We suggest that the location of the parasite in relation to the blood vessel is of major importance in determining the developmental success of a plasmodium. Co-occurrence of plasmodia of different developmental stages could be found, especially in spring. Development of spores in any one cyst, however, was synchronous. Host tissue surrounding plasmodia was always intact but $H$. creplini did have an obvious deleterious effect on its fish host by decreasing the respiratory surface of the gills. The structure of the $H$. creplini plasmodium wall is also described using transmission electron microsopy.
\end{abstract}

KEY WORDS: Henneguya creplini - Prevalence - Seasonality - Development - Plasmodium - Spore

\section{INTRODUCTION}

Myxosporean parasites are a significant group of parasitic protozoans, with more than 1330 species described (Lom \& Dykova 1992). Typically they occur in the organ cavities and tissues of fish, apparently having little or no deleterious effect. However, certain species are known to cause severe tissue reactions and occasionally the death of the host (Bartholomew et al. 1989, Lom \& Dykova 1992).

Henneguya Thelohan, 1892 is a widely distributed histozoic myxosporean genus that occurs especially on the gills of perch Perca fluviatilis, pike Esox lucius and channel catfish Ictalurus punctatus. Two distinct branchial forms of Henneguya infection, inter- and intralamellar, have been described. Many Henneguya species have been found at both sites (Minchew 1977.
Current \& Janovy 1978, Lom \& Dykova 1992). The interlamellar form is considered to be more pathogenic (Meyer 1970).

Symptoms of Henneguya infection may be vigorous. The gill tissue may lose its normal appearance and almost its entire respiratory function (McCraren et al. 1975), and affected fish often die rapidly when exposed to an oxygen deficiency (Dykova \& Lom 1978). Furthermore, affected fish do not tolerate handling, and attempts to treat them with parasiticides can cause additional losses (McCraren et al. 1975).

Certain forms of Henneguya are known to cause disease only under specific circumstances. Interlamellar Henneguya in channel catfish need rapid proliferation of gill epithelial tissue in order to cause subsequent myxosporeosis; such a condition exists, for example, in fast-growing fingerlings or fishes infected with ecto- 
parasites (Smith \& Inslee 1980). Environmental stress as a predisposing factor, together with overcrowding, increases the susceptibility of fish to infection by myxosporeans (El-Matbouli et al. 1992). The nature and degree of the pathogenic effect on the host are manifested in different ways and depend on many factors, such as the myxosporean species involved, its life cycle and biology, the host species, host age, state of nutrition and resistance to the parasite. A severe infection can also increase the susceptibility of the weakened fish to other diseases (Shulman 1966).

In this study the occurrence of Henneguya creplini (Gurley, 1894) on perch gills, the structure of its plasmodia and the possible host reaction against it were investigated on material collected from 4 Finnish lakes of differing water quality. Information concerning the seasonal cycle of Henneguya is scarce; therefore we also present information on this topic and on the developmental rhythm of $H$. creplini spores in perch.

\section{STUDY AREA}

The 4 lakes studied, Vatia, Saravesi, Peurunka and Leppävesi, are in central Finland close to the city of Jyväskylä. They are interconnected, but fish migration between them is prevented by strong rapids between Vatia and Saravesi, a dam between Peurunka and Vatia and a hydroelectric power station between Saravesi and Leppävesi. A map is given in Haaparanta et al. (1993). Water flows from Vatia to Saravesi and Leppävesi and its replacement time in the lakes is 3,4 and $32 \mathrm{~d}$, respectively. These lakes are eutrophic, and Vatia is also polluted by the effluent from a paper and pulp mill located $15 \mathrm{~km}$ upstream. The mill used organochlorines for the bleaching of pulp between the late 1950 s and 1992. Traces of pollutants can also be detected in Saravesi and Leppävesi. In relation to the eutrophic, polluted Lake Vatia, changes have been demonstrated in fish physiology (Oikari \& Soivio 1976), phytoplankton (Granberg et al. 1987) and benthic animal composition (Hynynen 1987, Meriläinen 1987). Lake Peurunka is connected to Vatia; it is an oligotrophic, unpoliuted lake, with a water replacement period of $3.4 \mathrm{yr}$.

The lakes are covered by ice between the second half of November and the beginning of May. Summer water temperatures reach $20^{\circ} \mathrm{C}$ in late July and early August. The summer of 1987 was cooler than in 1986: mean water temperatures at $4 \mathrm{~m}$ depth in 1986 were $6.9,13.6,18.0$ and $19.9^{\circ} \mathrm{C}$ in May, June, July and August, respectively, and in 1987 were 5.4, 12.7, 15.6 and $14.9^{\circ} \mathrm{C}$, respectively. At least 14 freshwater fish species occur in all of the lakes, of which roach Rutilus rutilus and perch are among the most common.

\section{MATERIALS AND METHODS}

Monthly or bimonthly samples of about 15 perch were collected between February 1986 and November 1987 by angling or ice-fishing from the 4 study lakes, totalling 711 fish. Only adult fish were collected, the majority being 3 to 6 yr old. Fish were killed immediately prior to examination and Henneguya plasmodia were studied from all 4 gill arches on one side of the body. Gill arches were studied using transmitted light at 10 to $40 \times$ magnification. Some plasmodia from each fish were selected, squashed between the slide and coverslip, and studied using 100 to $400 \times$ magnification in order to identify the species and developmental stages. 'Early developmental stages' were distinguished from 'developing spores', in which at least some developing polar capsules were seen. A third group consisted of plasmodia in which at least some spores were fully developed and had a fully developed tail. Species identification of Henneguya was possible only when mature spores were present.

For routine histological examination, a total of 153 perch were studied during 1989-1990. On average samples of 10 live perch were collected from the 4 lakes during autumn 1989 and winter, spring, summer and autumn 1990. For light microscopy, the gills of the fish were fixed in $10 \%$ neutral buffered formalin dehydrated in a graded alcohol series, cleared in xylene and embedded in paraffin wax. Sections cut at 7 to $8 \mu \mathrm{m}$ were stained with Harris' H\&E, according to Giemsa, and with Milligan's trichrome.

For transmission electron microscopy (TEM), small pieces of infected gills were fixed in phosphatebuffered $6.25 \%$ glutaraldehyde $\left(4^{\circ} \mathrm{C}, 3\right.$ to $\left.4 \mathrm{~h}, \mathrm{pH} 7.4\right)$, post-fixed in $1 \% \mathrm{OsO}_{4}$ for $2 \mathrm{~h}$, dehydrated in a graded acetone series and embedded in EPON 812. Semi-thin sections were stained with toluidine blue and safranine red. Ultrathin sections were contrasted with uranyi acetate and lead citrate and examined with a Zeiss EM 109 transmission electron microscope at $80 \mathrm{kV}$.

Statistical analyses were performed using the TABLES module of the SYSTAT statistical package. For likelihood ratio $\chi^{2}$ statistics see Sokal \& Rohlf (1981).

\section{RESULTS}

Henneguya creplini was found to occur on the gills of perch in all 4 lakes. $H$. psorospermica Thelohan, 1895 was also identified, but occurred only rarely, in less than $5 \%$ of infected perch. In most samples the majority of plasmodia contained developmental stages rather than mature spores and species identification was not possible. Macroscopically, $98 \%$ of the Hen- 
neguya plasmodia were observed between the secondary lamellae (Fig. 1) and the remainder were intralamellar. However, all plasmodia were found in the gill epithelium itself and did not destroy or perforate the epithelial basement membrane.

Early-stage plasmodia were in close contact with small capillaries and blood vessels, lacunae of the secondary lamellae or interlamellar capillaries (Fig 2). The plasmodial wall was in contact with the respiratory epithelium or its basement membrane, or was directly adjacent to the basement membrane of blood vessels (Fig. 3). Beneath the surface membrane of the plasmodium there was a fairly distinct zone composed of more or less homogeneous eosinophilic material of up to $2 \mu \mathrm{m}$ thickness. This peripheral region contained pinocytotic vesicles embedded in electron-lucent material (Figs. 3 \& 4). The border between the peripheral zone and the inner part containing sporogonic cells was regularly a system of very small vesicles forming a chain of fine membrane-like structures
Fig. 1. Henneguya sp. infecting Perca fluviatilis. Early plasmodia (*), including sporogonic stages between the secondary lamellae of the gills of perch. $H \& E, 220 \times$
Fig. 2. Henneguya sp. infecting Perca fluviatilis. Plasmodia in direct contact with host blood vessels $(x)$. 1: Peripheral homogeneous eosinophilic zone; 2 : developing spores. Semi-thin section, toluidine blue $1360 \times$
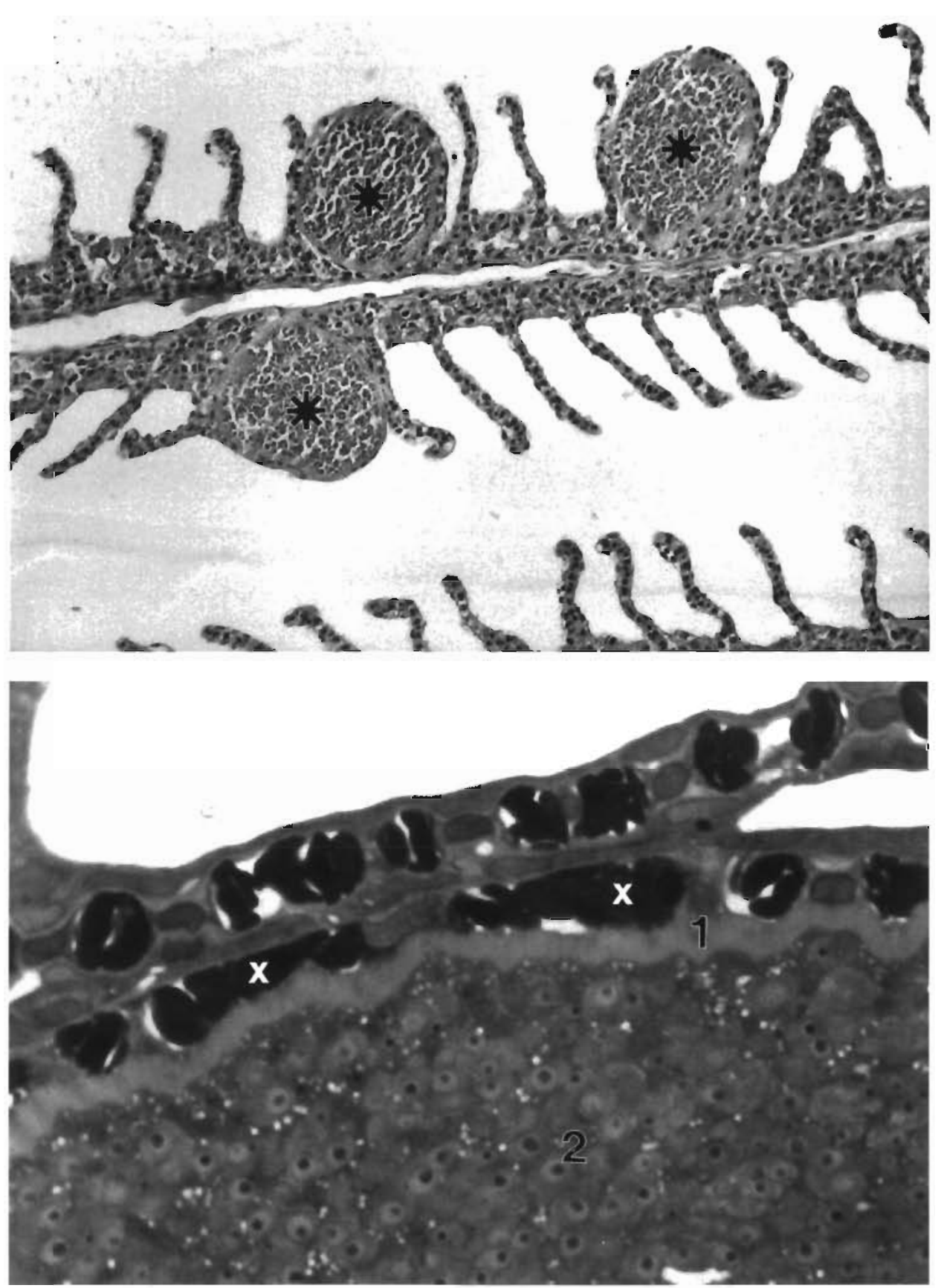
(Fig 4) Inside the plasmodium there were developing stages of sporogonic cells with glycogen deposits and residues of cell organelles of the plas. modial cell Mature plasmodia had pnncipally the same wall structure, but the developing sporogonic cells were replaced by mature and maturing spores with clearly detectable polar capsules. The development of spores was synchronous within any one plasmodium. Very young plasmodia containung early sporogonic cells were frequently seen next to the large mature plasmodia (Fig 5). In some cases, a large proportion of the respiratory epithelium of the lamellae was fused due to the plasmodia. In heavy infections, as seen in Fig. 5, there was even a $50 \%$ loss of the functional respiratory surface of the gills.

In large plasmodia, the respiratory epithelum can proliferate to a thickness of 10 or more cell layers in some places. All observed plasmodia were intact and no tissue reaction against the parasite, 1.e. accumulations of lymphocytes, granulocytes or macrophages, was observed. After the plasmodia were ruptured in

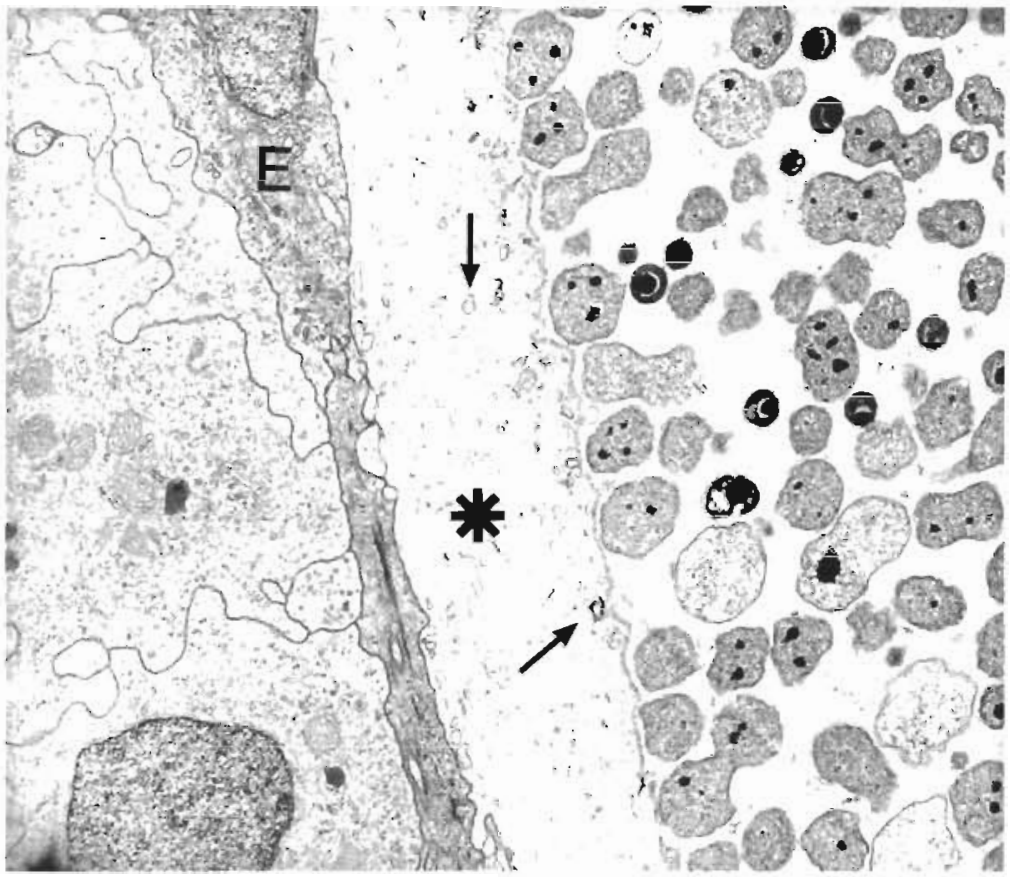

Fig 3 Henneguya creplin infectung Perca fluviatilis. Wall of the plasmodium adjacent to respiratory epithelium (E), which also fills the left side of the picture Penpheral homogeneous zone (*); pinocytotic vesicles are indicated by arrows. TEM, $8800 x$

spring or early summer, a focal inflammatory reaction with macrophages and granulocytes could be seen.

The prevalence of Henneguya creplini infection exhibited clear seasonal patterns in all of the lakes, both in 1986 and 1987, although the patterns differed between years (Fig. 6). The lowest prevalences in 1986 were found in midsummer and highest from February to May. The summer decrease was delayed in 1987, when the summer was cool. The variation was statistically significant in all of the lakes (likelihood ratio $\chi^{2}$ test, $p<0.001$ in all cases). The development of $H$. creplini also exhibited a clear seasonal cycle. Plasmodia with mature spores occurred not only in the spring and early summer of 1986 , but also in the summer and at the end of 1987. During the second half of 1986, only the early sporogonic stages were seen, and these stages commenced developing during early winter in 1987.

Henneguya creplini infection was found in all age groups of fish, but
Fig 4 Henneguya creplini Homogeneous penpheral zone of plasmodrum, consisting of a fine network of fibres and vesicles The border between this zone and sporogonic cells (S) is indıcated by arrows TEM, $38500 \times$ 
Fig. 5. Henneguya creplini infecting Perca fluviatilis. Co-occurrence of mature and early (arrows) plasmodia on the gills of perch. H\&E, $100 \times$

there was a definite tendency for younger perch to be more heavily infected in all of the lakes; the results for Lake Saravesi, for example, are 45 , $46.2,34.2,9.7$ and $11.7 \%$ for age groups $2,3,4,5$ and $6 \mathrm{yr}$, respectively, and for Lake Peurunka 65.2, 45.6, $40.8,40.9$ and $33.3 \%$ for these age groups. However, differences between the age groups were statistically significant only in Lakes Saravesi and Vatia (likelihood ratio $\chi^{2}$ test, $G=26.8, \mathrm{df}=4, \mathrm{p}<0.001$ and $G=14.7$. $\mathrm{df}=4, \mathrm{p}=0.005$, respectively).

When the total material from each lake was pooled, the prevalence of Henneguya infection was highest in the oligotrophic Lake Peurunka $(39.6 \%)$ and lowest in the eutrophic Saravesi $(26.5 \%)$ (Fig. 7), which was statistically significant (likelihood ratio $\chi^{2}$ test, $G=8.48$, df $=3, p=0.037$ ). In Lakes Peurunka and Leppävesi no difference was found during either of

Fig. 6. Henneguya creplini. Seasonal occurrence of plasmodia and their developmental stages on the gills of perch Perca fluviatilis from 3 lakes in central Finland between February 1986 and November 1987. Months indicated in Roman numerals
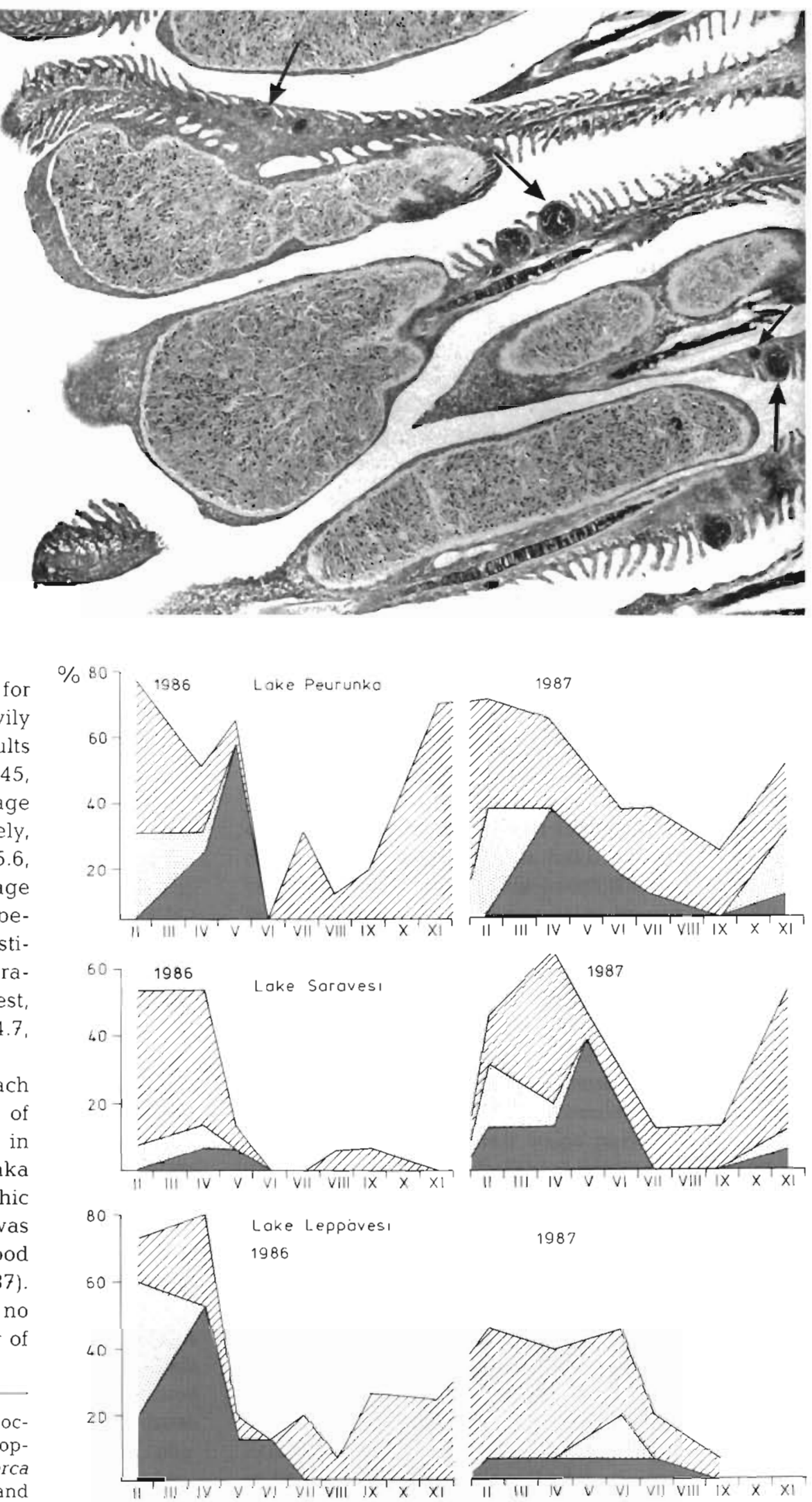

1987

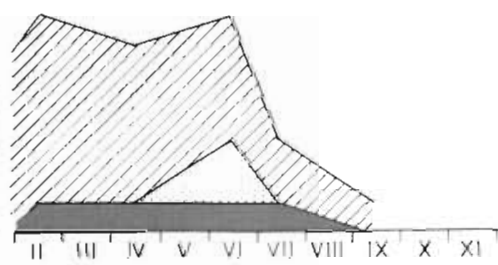

Qualst developmental stage $\square$ developing spores mature spores present 


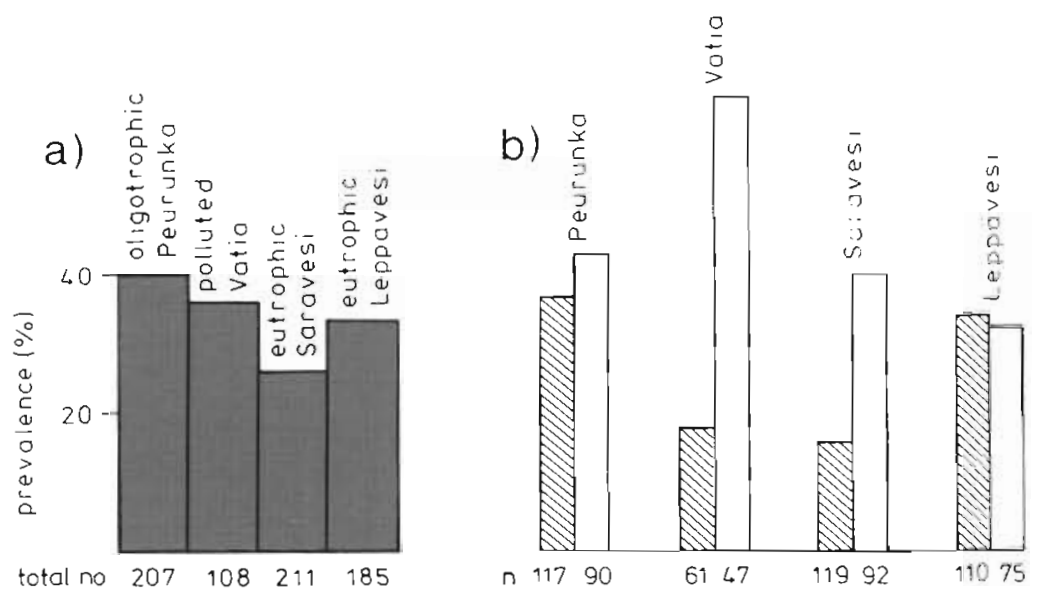

Fig. 7 Henneguya spp. Prevalences of infection on the gills of perch Perca fluviatilis in 4 lakes in central Finland. (a) Pooled material from the period February 1986 to November 1987; (b) separately for the 2 years studied

ences in the occurrence of plasmodia in the annually pooled material between the years 1986 and 1987 may be explained by temperature differences between the 2 years. The summer season was cooler in 1987 than in 1986, especially in May and at the end of summer. Higher total prevalences of Henneguya creplini in 3 of the lakes in 1987. as well as the delayed peak prevalences in May-June of 1987, may have been due to the colder water temperatures in that year, which also delayed the spawning of perch by about 2 wk. The maturation of spores had also significantly increased by April-May in 1987. At that time daylength had increased, although the water temperature was still only a few degrees and the fish were in spawn-

the 2 years. However, in the polluted Lake Vatia and the eutrophic Lake Saravesi, large differences in the prevalences were found between 1986 and 1987 (Fig. 7).

\section{DISCUSSION}

Pulp mill effluents have been shown to significantly decrease the antibody-mediated immunity of roach in Lake Vatia as compared to the oligotrophic Lake Peurunka (E. I. Jokinen, T. M. Aaltonen \& E. T. Valtonen unpubl.j. However, pollution did not have any influence on the level of Henneguya creplini infection in perch in the present study, which was similar in Lakes Peurunka and Vatia.

Infections of Henneguya psorospermica in perch and H. creplini in ruff Gymnocephalus cernuus have been considered limited to the cold season of the year (Dykova \& Lom 1978). Andrews (1979) found very prominent seasonal variation in the occurrence of mature spores of $H$. psorospermica in perch from Wales, UK. The plasmodia were absent at a time when the lake temperature exceeded $10^{\circ} \mathrm{C}$. In these cases the seasonality was suggested to be caused by an activated immune response of the fish during the warm water period According to Shulman (1989), H. creplini infection in perch takes place at water temperatures below $13^{\circ} \mathrm{C}$. He also stated that $H$. creplini has a $1 \mathrm{yr}$ life cycle, in contrast to Chloromyxum esocinum, $C$. mitenevi and Myxobolus cybinae for which he suggested a shorter life span. Our results also indicate a 1 yr life cycle for $H$. creplini in perch.

It has been suggested that weather conditions directly influence myxosporean seasonal changes (Shulman 1966, 1989). In the present study, the differ- ing condition. The disappearance of plasmodia in early summer may have been caused by increased immune reactivity related to low levels of corticosteroids and sex steroids during the post-mating period (see Zapata et al. 1992).

It has been suggested that the development of Henneguya plasmodia in ruff and perch is synchronous. This observation is based on the remarkably uniform size of the plasmodia (Dykova \& Lom 1978). In the present material plasmodia could be highly variable in size, especially in spring and early summer, when undeveloped small plasmodia were encountered among the plasmodia with mature spores. The presence of early developmental stages may be due to arrested or inhibited development of these plasmodia (see Duhamel et al. 1986), e.g. if the plasmodium has not reached an optimal position in relation to the host's blood system. Another possible explanation is that reinfection has occurred, which would also agree with some earlier studies, in which a relatively easy reinfection by myxosporeans has often been claimed (Lom \& Dykova 1992).

The seasonal variation in the prevalence and development of Henneguya may also be influenced by the presence of an intermediate host in the life cycle (see El-Matbouli et al. 1992). Nevertheless, there is no evidence so far that Henneguya does not have a monoxenic life cycle.

In the case of myxosporeans which parasitize organs, the sporoplasm penetrates the epithelium of the intestine and subsequently the intestinal wall, and reaches the relevant organ via either the blood or the lymphatic systems (Shulman 1966). Jakowska \& Nigrelli (1953) suggested that the widely dispersed occurrence of Henneguya visceralis in Electrophorus electricus may indicate that some stages of the parasite are trans- 
ported via the blood system. Furthermore, Greven (1956) and Dykova \& Lom (1978) stated that $H$. psorospermica planonts probably reach the target area in the gills via the blood stream. On the other hand, it could be that, in the case of Henneguya, reinfection takes place in the outer part of the gills immediately beneath the epithelium and the infective stages do not migrate through the body. Irrespective of the route of infection, however, we suggest that the final location of the parasite in relation to the blood vessels is of major importance in determining the developmental success of Henneguya plasmodia. Close contact with the blood system, as shown in the present work, may not induce an immune reaction, but may be necessary for an adequate supply of nutrients for the growing plasmodia.

The myxosporean plasmodium wall is considered to be a highly pinocytotic organelle (e.g. Current 1979). The structure of the plasmodium wall has been found to vary not only among species but also within species, according to the site of the plasmodium (Current \& Janovy 1978, Current 1979). This feature may prove to be a valuable taxonomic character for identifying myxosporean parasites (Current 1979). In the present study, the border between the peripheral zone and the inner part of the plasmodium was found to consist of a system of very small vesicles forming a chain of fine membrane-like structures. When our knowledge of the plasmodium wall ultrastructure increases, this structure may prove to be valuable in determining the species or subspecies implicated in Henneguya infections.

Studies on the immune response of the host against myxosporeans have yielded contradictory results (Bartholomew et al. 1989). Most researchers have been able to find little, if any, humoral host response to myxosporeans (Lom \& Dykova 1992). Descriptions of cell and tissue reactions against myxosporeans are also contradictory. Usually only a mild reaction against these parasites - or no reaction at all, as in the present case - has been reported (see e.g. Nigrelli \& Smith 1940, Hoshina 1952, Greven 1956, Kovacs-Gayer \& Molnar 1983), but some species or strains are also known to cause severe reactions in fish (see e.g. Meyer 1970, Amandi et al. 1985, Duhamel et al. 1986, Bartholomew et al. 1989). Nigrelli \& Smith (1940) stated that a severe inflammatory reaction in myxosporean infections is, in fact, a secondary inflammatory reaction caused by bacteria or fungi (see also Lom \& Dykova 1992).

In this study, the host tissue surrounding the plasmodia was always intact. An explanation for the lack of a host response to Henneguya may be that the plasmodial wall is not antigenic. Furthermore, most plasmodial development occurred at a time during the year when the lymphoid tissues of lower vertebrates are suggested to have a general trend towards a transient regression (Zapata et al. 1992). However, the present study has confirmed that $H$. creplini has an obvious deleterious effect on its host, by decreasing the respiratory surface of the gills.

Acknowledgements. This study was financed by the Research Council for the Environmental Sciences, Academy of Finland. We thank Messrs Aarre Valkonen, Olavi Järvinen and Pekka and Juha Manninen for catching the fish for this study. Drs D. I. Gibson and Roy Siddall kindly checked the English of this manuscript.

\section{LITERATURE CITED}

Amandi, A., Holt, R. A., Fryer, J. L. (1985). Observations on Myxobolus insidiosus (Myxozoa: Myxosporea), a parasite of salmonid fishes. Fish Pathol. 20:287-304

Andrews, C. (1979). The occurrence of Henneguya psoros. permica Thelohan, 1895 (Myxosporida) on perch, Perca fluviatilis L., from Llyn Tegid, Wales. J. Fish Dis. 2: 27-33

Bartholomew, J. L., Smith, C. E., Rohovec, J. S., Fryer, J. L. (1989). Characterization of a host response to the myxosporean parasite, Ceratomyxa shasta (Noble), by histology, scanning electron microscopy and immunological techniques. J. Fish Dis. 12: 509-522

Current, W. L., Janovy, J. Jr (1978). Comparative study of ultrastructure of interlamellar and intralamellar types of Henneguya exilis Kudo from channel cattish. J. Protozool. 25: $56-65$

Current, W. L. (1979). Henneguya adiposa Minchew (Myxosporida) in the channel catfish: ultrastructure of the plasmodium wall and sporogenesis. J Protozool. 26: 209-217

Duhamel, G. E., Kent, M. L., Dybdal, N. O., Hedrick, R. P. (1986). Henneguya exilis Kudo associated with granulomatous branchitis of channel catfish Ictalurus punctatus (Rafinesque). Vet. Pathol. 23: 354-361

Dykova, I., Lom, J. (1978). Histopathological changes in fish gills infected with myxosporidian parasites of the genus Henneguya. J. Fish Biol. 12: 197-202

El-Matbouli, M., Fischer-Scherl, T., Hoffmann, R. W. (1992). Present knowledge on the life cycle, taxonomy, pathology, and therapy of some Myxosporea spp. important for freshwater fish. A. Rev. Fish Dis. 367-402

Granberg, K., Hynynen, J., Meriläinen, J. J., Mäkelä, H., Palomäkj, A., Bibiceanu, S. (1987). Limnological studies of the watercourse Aänekoski in 1987. Rep. Inst. Environ. Res., Univ. of Jyväskylä (in Finnish)

Greven, U. (1956). Ein Beitrag zum Verhalten von Myxosporidien in den Kiemen einiger Süsswasserfische. Z. Fisch. Deren Hilfswiss. 5: 110-114

Haaparanta, A., Valtonen, E. T., Hoffmann, R. W. (1993). Heart inflammation in perch Perca fluviatilis and roach Rutilus rutilus from central Finland. Dis. aquat. Org. 17: 25-32

Hoshina, T. (1952). Notes on some myxosporidian parasites of fishes in Japan. J. Tokyo Univ. Fish. 39: 69-89

Hynynen, J. (1987). Snails and small mussels (Sphaeriidae) of Lake Päijänne and some adjacent lakes. Biol. Res. Rep. Univ. Jyväskylä 10: 115-118

Jakowska, S., Nigrelli, R. F. (1953). The pathology of myxosporidiosis in the electric eel. Electrophorus electricus (Linnaeus), caused by Henneguya visceralis and $H$. electrica spp. nov. Zoologica 38: 183-191

Kovacs-Gayer, E., Molnar, K. (1983). Studies on the biology and pathology of the common carp parasite Myxobolus 
baslamellaris Lom et Molnar, 1983 (Myxozoa: Myxosporea). Acta vet. Hung. 31: 91-102

Lom, J., Dykova, I. (1992). Protozoan parasites of fishes. Developments in Aquaculture and Fisheries Science 26. Elsevier, Amsterdam

McCraren, J P., Landolt, M. L., Hoffman, G. L., Meyer, F. P. (1975). Variation in response of channel catfish to Henneguya sp. infections (Protozoa: Myxosporidea). J. Wildl. Dis. $11.2-7$

Meriläinen, J. J. (1987). The profundal zoobenthos used as an indicator of the biological condition of Lake Päijänne. Biol. Res. Rep. Univ. Jyväskylä 10: 87-94

Meyer, F. P. (1970). Henneguya infections. In: Progress in sport fishery research 1969. U.S. Bureau of Sport Fisheries and Wildlife, Publ. 88, Washington, DC, p. 160-161

Minchew, C. D. (1977). Five new species of Henneguya (Protozoa: Myxosporida) from ictalurid fishes. J. Protozool. 24: $213-220$

Nigrelli, R. F., Smith, G. M. (1940). A papillary cystic disease affecting the barbels of Ameiurus nebulosus (Le Sueur),

Responsible Subject Editor: W. Körting, Hannover, Germany caused by the Myxosporidian Henneguya ameiurensis sp. nov. Zoologica 25: 89-96

Oikari, A., Solvio, A. (1976). Physiological condition of fish exposed to water containing pulp and paper industry wastes and sewage. In: Alabaster, J. S (ed.) Biological monitoring of inland fisheries. Appl. Sci. Publ., London, p. $89-96$

Shulman, B. S. (1989). Zhiznennye tsikly nekotorykh miksosporidii ryb Kol'skogo poluostrova. Parazitologiya 23 $216-221$

Shulman, S. S. (1966). Miksosporidii Fauny SSSR. Nauka Publishers, Moscow. (English translation 1990)

Smith, C. E., Inslee, T (1980). Interlamellar Henneguya infestation in adult channel catfish Ictalurus punctatus (Rafinesque). J. Fish Dis. 3: 257-260

Sokal, R. R., Rohlf, F. J. (1981). Biometry. Freeman, San Francisco

Zapata, A. G., Varas, A., Torroba, M. (1992). Seasonal variations in the immune system of lower vertebrates. Immunol. Today 13: $142-147$

Manuscript first received: December 16, 1993

Revised version accepted: July 17, 1994 